\title{
Abundance of Potential Pathogenic Bacteria in an Impacted Urban River used for Domestic Purposes: Djibi River, Ivory Coast
}

\author{
Cyr-Kevin Yao Kouamé1,*, Nouho Koffi Ouattara ${ }^{1}$, Comoé Koffi Donatien Benie ${ }^{2}$, Ehouman Serge Koffi ${ }^{3}$, \\ Bamory Kamagaté ${ }^{3}$, Droh Lanciné Goné ${ }^{3}$, Allassane Ouattara ${ }^{1}$, Germain Gourène ${ }^{1}$
}

${ }^{1}$ Laboratory of Fisheries and Aquaculture Research Center, UFR-SGE, Nangui Abrogoua University, 02 BP 801 Abidjan 02, Ivory Coast.

${ }^{2}$ University of Félix Houphouët Boigny, Laboratory of Biotechnology and Food (LBF), 01 BP V4 Abidjan 01, Ivory Coast.

${ }^{3}$ Laboratory of Geosciences and Environment, Nangui Abrogoua University, 02 BP 801 Abidjan 02, Ivory Coast.

\section{AR T I C LEDETA ILS}

\section{Article history:}

Received 21 June 2019

Accepted 05 July 2019

Available online 17 July 2019

\section{Keywords:}

Vibrio sp.

Salmonella sp.

Health Risk

Djibi River

Ivory Coast

\begin{abstract}
A B S T R A C T
This study aims to quantify potential pathogenic bacteria and analyze the seasonal variability of pathogens from Djibi, the most important river crossing Abidjan city's border receiving sewage waters from the densely populated area of Abobo, in Ivory Coast, in order to evaluate potential health risk for the users of these waters. Then, 36 samples of river waters were collected in sterile bottles at 4 stations (Djibi sand careers, Djibi cemetery, Djibi garbage and Djibi bridge) from January 2016 to February 2017 during nine sampling campaigns to detect presence and abundance of Salmonella sp. and Vibrio sp. The median abundances of pathogenic bacteria ranged between $8.65 \times 10^{3}$ and $7.60 \times 10^{3} \mathrm{CFU}$ of Vibrio sp. $(100 \mathrm{~mL})^{-1}$. The highest abundance values were recorded in Djibi sand careers and Djibi garbage with concentrations of $3.75 \times 10^{4}$ and $4.37 \times 10^{4}$ Vibrio sp. $(100 \mathrm{~mL})^{-1}$ respectively. We also observed that Salmonella sp. were present in all the samples analyzed. This clearly indicates a potential risk when using these waters for irrigation and domestic purposes. The natural connection of this river to the potential drinking water reservoir of Aghien represents a significant public health hazard.
\end{abstract}

\section{Introduction}

Surface water pollution is a major global problem that requires continuous evaluation and revision of policies related to its use and protection. Polluted water is regarded as the leading cause of deaths and diseases worldwide [1]. A number of factors continue to negatively impact natural water resources across the world, many of which primarily result from anthropogenic activities, while urbanization and industrialization are regarded as most effective [2]. It is estimated that over $90 \%$ of wastewater from various sources especially from domestic, industrial and agricultural activities are discharged into lakes, rivers and other aquatic systems across the world [3,2].

Unfortunately, the lack of sanitation and wastewaters treatment plants still lead to discharge significant amounts of fecal indicators bacteria and pathogenic microorganisms which impair the quality of water in the receiving watersheds [4]. The pathogens most frequently transmitted through water are those which cause infections of the intestinal tract; namely, typhoid and para-typhoid bacteria, dysentery, cholera bacteria and enteric viruses [5]. The causative organisms of these diseases are present in the feces or urine of an infected person, and when discharged may gain entrance into a water body that ultimately serves as a source of drinking water [6]. Among the pathogens disseminated in different aquatic environments, enteric pathogens such as Vibrio and Salmonella are the ones most frequently encountered $[7,8]$. The [9] estimates that every year about 2.2 million people die from diarrheal diseases; $90 \%$ of these deaths are among children, mostly in developing countries.

Rapid population growth with urbanization poses a serious problem in relation to drinking water supply in Ivory Coast [4]. Studies by [10] showed that the production of wastewaters caused by human activities exposes urban areas to major health risks linked to the presence of any pathogens. Indeed, the city of Abidjan knows since January 2011, a reemergence of diarrheal diseases (including cholera) after 6 years of relative disappearance $[11,12]$. In addition, climate change, with warming temperatures could affect the persistence of some pathogens even some

epidemics. [4] on the other hand reported that the level of risk depends on contamination's level.

Located in peri-urban area along the eastern Ivorian coastal, the Djibi river is the most polluted of Aghien lagoon watershed receiving sewage waters from the densely populated area of Abobo, [4] and is characterized by a high urbanization [13]. The consequence is forests degradation in aid of settlements and agriculture. This implies the Djibi river tributary serves not only as critical source of water for domestic use for the locals, but also as conduits for waste and raw sewerage that often contaminate water resources [4]. It is now well known that sewage brings high loads of organic and inorganic pollutants that strongly modify the habitat of native freshwater bacteria. For instance, basic parameters such as temperature, $\mathrm{pH}$ and dissolved oxygen which are known as drivers of the bacterial community composition $[14,15]$ in aquatic systems can be influenced by urban wastewater discharges. Actually, the monitoring program to evaluate Djibi river's water quality quoted that the abundances of faecal indicators were the highest amongst the Aghien watershed main tributaries [4] warranted inclusion of pathogenic bacteria to prevent the sanitary risk associated with freshwaters [16]. This study sought to assess pollutant levels by use of genera Vibrio sp. and Salmonella sp. of health hazard including as well as physical and chemical parameters levels (temperature, $\mathrm{pH}$ and dissolved oxygen) and Vibrio sp. seasonal variation. It will therefore be of general importance and can be widely applied to other river systems faced with similar challenges to that of the Djibi river.

\section{Experimental Methods}

\subsection{Study Area}

The study area is Djibi river, one of main tributaries of the Aghien lagoon watershed. It is located on the north-eastern of the Abidjan city (economic capital of Ivory Coast) $[17,18,13]$. It is limited to the north by the sub-prefecture of Azaguié and to the south by that of Bingerville. The Djibi sub-basin crosses the peripheries of two urban localities (Abobo and Anyama) and covers an area of $78 \mathrm{~km}^{2}$ for a perimeter of $77 \mathrm{~km}$. Its altitude varies from 12 to $135 \mathrm{~m}$ [13].

The Djibi river joins the Aghien lagoon, a potential drinking water reservoir. Some other small tributaries (Djibi sand careers, Djibi garbage, 
Djibi cemetery and Djibi bridge) (Fig. 1) located in the Djibi river sub-basin are diverted in the Djibi river so that their waters reach Aghien lagoon. The Djibi river receives domestic sewage from Anyama, Abobo, Brofodoume municipalities and villages located in the watershed without any treatment [4].

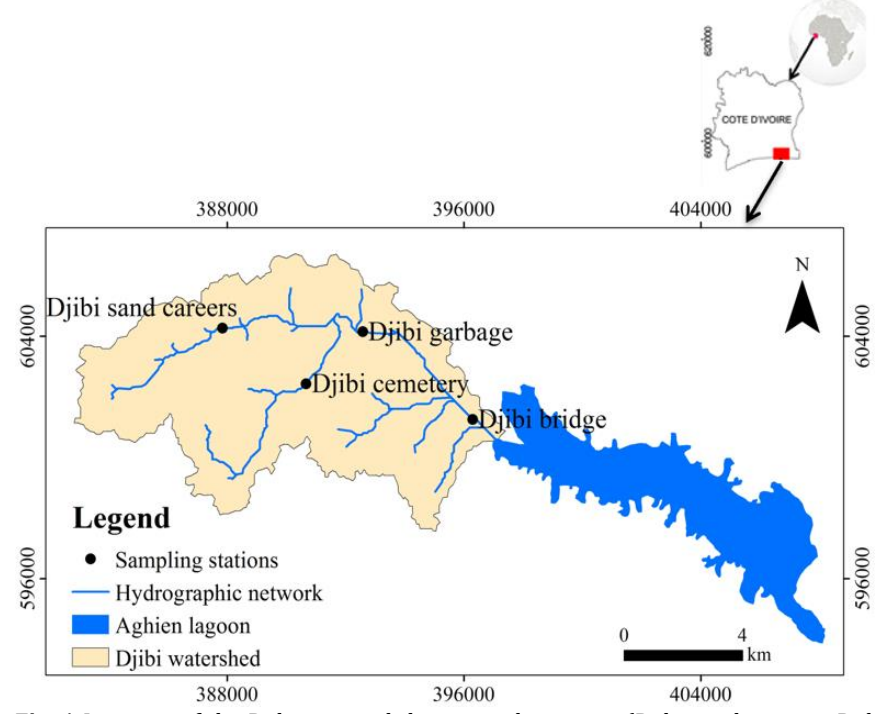

Fig. 1 Location of the Djibi river sub-basin creek stations (Djibi sand careers, Djibi garbage, Djibi cemetery and Djibi bridge)

\subsection{Sample Collection and Processing}

In this study, total of 36 water samples were examined over a period of 9 months, from January 2016 to February 2017. Totally, 9 sampling campaigns were thus performed in four different creeks of Djibi sub-basin. For each creek, 9 samples were collected and stored in $100 \mathrm{~mL}$ sterile bottles. All the bottles were labeled with the source name, date and time of samples collection. The bottles were transported to the laboratory, kept at $4{ }^{\circ} \mathrm{C}$ and processed within a maximum of $2 \mathrm{~h}$ after collection for microbiological analysis.

\subsection{Physical and Chemical Parameters}

Temperature, $\mathrm{pH}$ and dissolved oxygen are some of the important factors that play a vital role in the growth of microorganisms in the water body [19]. Their importance on the evaluation of water quality affected by sewage waters is well described by Errich et al. [20]. In the scope of this study, three parameters were measured directly on site during the whole study period. Temperature, dissolved oxygen and $\mathrm{pH}$ were measured using multi-parameter $\mathrm{HACH} \mathrm{HQ} 40 \mathrm{D}$, according to standardized protocols of Rodier et al. [21]. Results of physic and chemical parameters were expressed as maximum, median and minimum.

\subsection{Bacterial Isolation}

2.4.1 Quantitative Enumeration of Enteropathogens: Vibrio sp. and Salmonella sp.

Vibrio sp. was isolated and enumerated in water samples by applying standard plate count technique using a selective TCBS (thiosulphate citrate bile salt sucrose agar) (OXOID LTD, CM0333, England) agar media. The protocol used to detect Vibrio sp. is well described by [22]. Briefly, for Vibrio sp. enumeration, $100 \mu \mathrm{L}$ of the water sample was plated or spread one or more successive decimal dilutions thereof directly into sterile Petri dishes in triplicate, onto which was added TCBS agar media when a high concentration of pathogenic bacteria is presumed. Also, the filtration of a very precise volume of the sample $(1 \mathrm{~mL}, 10 \mathrm{~mL}$ or $100 \mathrm{~mL})$ on a sterile filter membrane (porosity $0.45 \mu \mathrm{m}$ and pore diameter $47 \mathrm{~mm}$ ) was carried out for lower expected concentrations in bacteria and the filter was gently deposited on the agar. For $1 \mathrm{~mL}$ of sample, a sufficient volume of sterile Ringer's solution was added to the funnel to obtain a good distribution of bacteria over the entire filter surface. TCBS agar media were incubated at $37^{\circ} \mathrm{C}$ for $24 \mathrm{~h}$ before enumeration. Plate counts were expressed as colony forming units (CFU) per $100 \mathrm{~mL}$ of sample.

All the samples were analyzed for Salmonella sp. detection according to the horizontal reference standard NF EN ISO 6579 [23] by applying only Plate Method, except for serotyping. Nine $\mathrm{mL}$ of buffered peptone water BPW (Bio-Rad, Marnes La Coquette, France) was added to $1 \mathrm{~mL}$ of water sample, and broth was incubated at $37^{\circ} \mathrm{C}$ for $24 \mathrm{~h}$. After pre enrichment, $0.1 \mathrm{~mL}$ of the BPW was drawn off enrichment broth and replaced with 10 $\mathrm{mL}$ of Rappaport Vassiliadis Soya (RVS). After incubation at $42^{\circ} \mathrm{C}$ for $24 \mathrm{~h}$, a loopful of each enrichment broth was streaked onto Salmonella Shigella https://doi.org/10.30799/jespr.170.19050301
(SS) (CONDA, Spain) and Xylose Lysine Desoxycholate (XLD) (Himedia, Inde) agar used as selective and differential medium for the isolation of Salmonella sp. Plates were incubated at $37^{\circ} \mathrm{C}$, and salmonella-like colonies were picked at $24 \mathrm{~h}$ for biochemical confirmation.

\subsubsection{Biochemical Confirmation of Vibrio sp.}

All the yellow (sucrose-fermenting) and blue-green (non-sucrose fermenting) colonies on TCBS agar plates were considered as total Vibrio colonies and counted. Four characteristics of each presumptive colony were sub cultured on Plate Count Agar (PCA) supplemented with $\mathrm{NaCl}(2$ $\%$ ) (Bio-Rad) and incubated at $37^{\circ} \mathrm{C}$ for $24 \mathrm{~h}$. All giving a positive oxidase test was confirmed as Vibrio. All colonies were stored at room temperature for further testing.

\subsubsection{Biochemical Confirmation of Salmonella sp.}

Colonies of presumptive Salmonella sp. (black centered and light transparent zone of reddish colour on Xylose-Lysine-Desoxycholate (XLD) agar, colourless and black centered on Salmonella-Shigella (SS) agar) isolated were subjected to biochemical characterization such as Urease production test, Indole production test, Motility test and reduced rack of Leminor.

\subsection{Statistical Analysis}

Statistical analyses were performed to examine the component distribution and the mean difference between Vibrio sp., observed in creeks over the seasons, Kruskall-Wallis and $U$ Mann-Whitney tests with a significance level of 0.05 were used and applied by RSTUDIO 0.98 .490 software.

\section{Results and Discussion}

\subsection{Physical and Chemical Characteristics of Djibi River Creeks}

A summary of the physical and chemical characteristics of the Djibi river creeks is illustrated in Table 1. The water $\mathrm{pH}$ in Djibi sub-basin creeks ranged from 5.49 to 7.89 . The water temperature varied between $25^{\circ} \mathrm{C}$ and $31.9^{\circ} \mathrm{C}$ for Djibi bridge (D4) and Djibi garbage (D3) while in Djibi sand careers (D1) and Djibi cemetery (D2) temperature values were between $25.8{ }^{\circ} \mathrm{C}$ and $33.4{ }^{\circ} \mathrm{C}$, respectively. In the Djibi cemetery, the temperature was generally higher than that of the other creeks. Dissolved oxygen values were around $0.13-5.23 \mathrm{mg} / \mathrm{L}$ for D2, D3 and D4. The values of dissolved oxygen observed in the D2 were particularly low (less than 0.13 $\mathrm{mg} / \mathrm{L}$ along the river) and the relatively high values were observed in the Djibi sand careers (D1) $(6.98 \mathrm{mg} / \mathrm{L})$. None significant difference (KruskallWallis; $\mathrm{p}>0.05$ ) was observed for $\mathrm{pH}$ and temperature values between the Djibi sub-basin creeks during all the campaigns. However, dissolved oxygen values obtained were significantly different (Mann Whitney; $\mathrm{p}<$ 0.05) in D1 compared to those of D2, D3 and D4. A significant difference was also noticed between D3 and D4 for dissolved oxygen values (Mann Whitney; $\mathrm{p}<0.05$ ).

For each of these parameters, the high values were observed during the rainy season (RS) and the low values were observed in the dry season (DS).

Table 1 Physical and chemical parameters measured in the Djibi river creeks compared to WHO standards

\begin{tabular}{lllllll}
\hline & $\begin{array}{l}\text { Djibi sand } \\
\text { careers }\end{array}$ & $\begin{array}{l}\text { Djibi } \\
\text { cemetery }\end{array}$ & $\begin{array}{l}\text { Djibi } \\
\text { garbage }\end{array}$ & Djibi bridge & & \\
\hline $\mathrm{Nb}$ & 5 & 5 & 5 & 5 & WHO & $\mathrm{p}$ \\
& $\begin{array}{l}\text { Med } \\
\text { (Min-Max) }\end{array}$ & $\begin{array}{l}\text { Med } \\
\text { (Min-Max) }\end{array}$ & $\begin{array}{l}\text { Med } \\
\text { (Min-Max) }\end{array}$ & $\begin{array}{l}\text { Med } \\
\text { (Min-Max) }\end{array}$ & & \\
\hline $\mathrm{pH}$ & 6.20 & 7.17 & 6.54 & 6.67 & $6,5-8,50.17$ \\
& $(5.49-6.97)^{\mathrm{a}}$ & $(6.37-7.89)^{\mathrm{a}}$ & $(6.22-6.94)^{\mathrm{a}}$ & $(6.5-7.02)^{\mathrm{a}}$ & & \\
$\mathrm{Temp}$ & 28.40 & 26.80 & 26 & 25.2 & 25 & 0.62 \\
$\left({ }^{\circ} \mathrm{C}\right)$ & $(25.8-33.1)^{\mathrm{a}}$ & $(25.83-33.4)^{\mathrm{a}}$ & $(25.3-30.2)^{\mathrm{a}}$ & $(25-31.9)^{\mathrm{a}}$ & & \\
$\mathrm{DO}$ & 5.70 & 1.57 & 4.19 & 1.47 & $\geq 6$ & 0.003 \\
$(\mathrm{mg} / \mathrm{L})$ & $(4.4-6.98)^{\mathrm{a}}$ & $(0.13-3.7)^{\mathrm{bc}}$ & $(1.61-5.23)^{\mathrm{b}}(0.57-2.67)^{\mathrm{c}}$ & & \\
\hline
\end{tabular}

Values on the same line having different letters in exponent differ significatively (Kruskal-wallis ; $p$ <0,05); Min: Minimum; Med: Median; Max: Maximum; $p H$ : Hydrogen potential; Temp: temperature; DO: Dissolved Oxygen; Nb: Number

The $\mathrm{pH}$ values recorded across the period of sampling campaigns were slightly neutral $(\mathrm{pH} \geq 6.2 \leq 7.8)$ even if acidity $\mathrm{pH}$ in this study was observed. $\mathrm{pH}$ values observed were lower than those of WHO standards of $6.5-8.5$. The reports of Abowei et al. [24] suggested that waters with low change of $\mathrm{pH}$ are generally more conductive to aquatic life as it is the case in the Djibi river. 
Globally, temperature values observed were higher than the W.H.O standard of $25^{\circ} \mathrm{C}$. The values of temperature observed are too close the growing temperature of enteric bacteria. Then, the possibility of enteric bacteria growth cannot be neglected in these waters. The Djibi river creeks samples were also characterized by a very contrasting dissolved oxygen concentration which covered a range from $0.13 \mathrm{mg} / \mathrm{L}$ to $5.23 \mathrm{mg} / \mathrm{L}$. These values were lower than those of the W.H.O standard of $\geq 6 \mathrm{mg} / \mathrm{L}$. The low dissolved oxygen values were attributed to the discharge of organic wastes and nutrient inputs from sewages, agricultural run-off that find its way into the water body through erosion [25].

The low level and decline of dissolved oxygen in the study stations depicted a high level of organic pollution which resulted to biodegradation process by biotic microorganisms [26]. Otherwise, statistical analysis showed a significant difference $(p=0.003)$ for the dissolved oxygen between D1 and those from Djibi river sub-basin (D2, D3 and D4) and between D3 and D4 indicating that water oxygenation seems to be different in the Djibi river.

\subsection{Vibrio sp. Abundances and Salmonella sp. Detection from the Sampled Creeks in Djibi River Sub-basin}

The results obtained from the creeks constitute a good illustration (Fig. 2) of the very well-known contamination of Vibrio sp. in order to establish the public health regarding Djibi's water uses. Recorded abundance values for Vibrio sp. in waters exhibited or showed different levels. The less contaminated sites D3 and D4 had median abundances of $8.65 \times 10^{3}$ Vibrio sp. per $100 \mathrm{~mL}$ and $7.60 \times 10^{3}$ Vibrio sp. per $100 \mathrm{~mL}$, respectively while the most contaminated site D1 and D2 had median abundances of $3.75 \times 10^{4}$ Vibrio sp. per $100 \mathrm{~mL}$ and $4.37 \times 10^{4}$ Vibrio sp. per $100 \mathrm{~mL}$. For this potential pathogenic bacteria abundance, a significant difference was shown between D2, D4 and D3, D4 (Mann Whitney; $\mathrm{p}<0.05$ ).

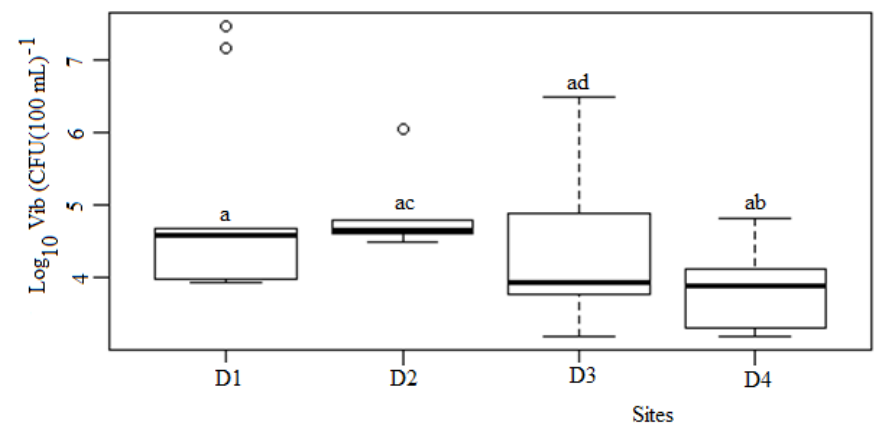

Fig. 2 Box plots in log units of the abundance of Vibrio sp. measured in the small creeks of the Djibi river sub-basin during the campaigns $(\mathrm{n}=36, \mathrm{D} 1=$ Dibi sand careers, D2 $=$ Djibi cemetery, D3 $=$ Djibi garbage, D4 $=$ Djibi bridge). Box plots represent the median (horizontal line in the box), the lower and upper quartiles (bottom and top box lines). Sites with at least one common letter have no significant difference. Those without common letter are significantly different

Our results showed that all the water samples were contaminated by Salmonella sp. Biochemical characteristics of all strains are mentioned in Table 2.

Table 2 Biochemical tests of Salmonella sp.

\begin{tabular}{lllll}
\hline Creeks & D1 & D2 & D3 & D4 \\
\hline Production of oxidase & $(-)$ & $(-)$ & $(-)$ & $(-)$ \\
Production of catalase & $(+)$ & $(+)$ & $(+)$ & $(+)$ \\
Production of $\mathrm{H}_{2} \mathrm{~S}$ & $(+)$ & $(+)$ & $(+)$ & $(+)$ \\
Production of gas & $(-)$ & $(-)$ & $(-)$ & $(-)$ \\
Fermentation of glucose & $(+)$ & $(+)$ & $(+)$ & $(+)$ \\
Fermentation of lactose & $(-)$ & $(-)$ & $(-)$ & $(-)$ \\
Lysine décarboxylase & $(+)$ & $(+)$ & $(+)$ & $(+)$ \\
Production of urease & $(-)$ & $(-)$ & $(-)$ & $(-)$ \\
Production of tryptophan & $(-)$ & $(-)$ & $(-)$ & $(-)$ \\
Fermentation of mannitol & $(+)$ & $(+)$ & $(+)$ & $(+)$ \\
Carbone using & $(-)$ & $(-)$ & $(-)$ & $(-)$ \\
\hline
\end{tabular}

$(+)$ : Positive reaction; (-): Negative reaction

Vibrio sp. and Salmonella sp. represent important epidemic pathogens $[27,28]$. The genus Salmonella is considered as an endemic public-health concern worldwide and has been involved in water-borne disease of humans and animals [29].

All sampling sites (Djibi sand careers, Djibi garbage, Djibi cemetery and Djibi bridge) showed the presence of Salmonella. The fact that these sites were located in the proximity of villages around the Djibi river may explain their presence due to direct discharge of feces. These pathogens have https://doi.org/10.30799/jespr.170.19050301 frequently been found in effluents from sewage, in industrial wastes, and in streams that receive a variety of sewages and industrial wastes [30] This frequent isolation of Salmonella sp. from the creeks' water of Djibi sub-basin gives rise to questions such as their load, their survival or persistence, and their interaction with aquatic organisms like fish [28]. Salmonellosis is more commonly associated with contaminated foods so that fish appear to be passive carriers of salmonella.

In all sampling sites, Vibrio sp. was also present with levels of concentration suggesting an important sanitary risk for domestic water uses and irrigation. Vibrio cholerae is often transmitted by water and other foods (Fish) contaminated water or faeces from infected persons [31]. People most often get infected as follows [32]: (i) through contact with infected fish while handling them, after injuries from fish or (ii) orally by consumption infected fish or related products or food contaminated with water or other constituents of water environment. Then, fishing activities may be compromised by the presence and the high abundance of Vibrio in these waters.

3.3 Seasonality of Vibrio sp. Abundance Description Along the Djibi Subbasin Watershed

In this section, all the samples from each sampling campaigns have been grouped following the seasonal repartition (dry and rainy season) and the two groups have been compared in order to evaluate the seasonal impact. Fig. 3 presents box plots in log units of the abundance of Vibrio sp. for different seasons (rainy season (RS) and dry season (DS)). Beside its high abundances recorded, influence of the RS and DS on Vibrio sp. has been analyzed along Djibi river watershed (Figure 3). So, this abundance variability was between $1.56 \times 10^{3}-2.99 \times 10^{7}$ Vibrio sp. per $100 \mathrm{~mL}$ of sample with the lowest values observed in DS and the highest values, in the RS. The median of the Vibrio sp. abundances recorded was $1.95 \times 10^{4}$ CFU per $100 \mathrm{~mL}$ in DS and a gradually increasing trend was observed in RS with $2.51 \times 10^{5} \mathrm{CFU}$ per $100 \mathrm{~mL}$. None significant difference (MannWhitney; $\mathrm{p}>0.05$ ) was observed for Vibrio sp. abundance concerning rainy season and dry season.

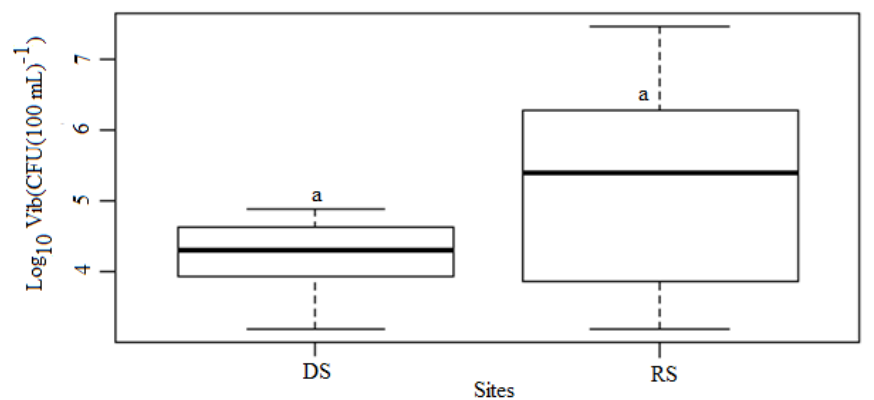

Fig. 3 Box plots in log units showing the seasonal abundance of Vibrio sp. variability in Djibi river sub-basin $(\mathrm{n}=36, \mathrm{DS}=$ dry season and $\mathrm{RS}=$ rainy season, $\mathrm{a}=\mathrm{no}$ significant difference)

The comparison of Vibrio sp. abundance along the Djibi sub-basin watershed during dry and rainy seasons showed that the lowest abundances were observed in dry season and the highest values, in the rainy season. We observed that there are less than 2 log unit variations in dry season but more than 3 log unit variations in rainy season. In the rainy period, surface runoff and septic tank overflow waters containing pathogenic microorganisms are discharged into the river. This may explain why there is this significant variation during the same rainy period. When comparing the average concentrations of dry and rainy seasons, there is no significant difference observed. The absence of significant difference could be explained by the few samples collected (only 36 samples) which may create a biais in the results interpretation [33]. Worden et al. [34] argued that Vibrio cholerae can increase its rates in waters with ongoing local anthropogenic influences. Results also shows that in rainy $\left(2.51 \times 10^{5} \mathrm{CFU}\right.$ per $\left.100 \mathrm{~mL}\right)$ and dry $\left(1.95 \times 10^{4} \mathrm{CFU}\right.$ per 100 $\mathrm{mL}$ ) seasons, the Vibrio sp. abundances observed were higher than the levels required for direct transmission to human even if the real level of exposure required to contract cholera is difficult to precisely assess [35]. Based on the current data, outcomes are in all likelihood the same, where Vibrio sp. outbreaks during the rainy season appear to reemerge from persistent transmission foci insufficiently tackled during the dry season reported by Rebaudet et al. [36].

\section{Conclusion}

The low concentrations of dissolved oxygen and abundances of two pathogenic micro-organisms (Vibrio sp. and Salmonella sp) in the Djibi 
river indicate that this river is highly polluted by sewage waters. Then, present uses (domestic purposes) are not required due to its poor quality. Important variation of Vibrio sp. in this river associated to the rainy and dry seasons, suggested that season could impact the abundance of Vibrio sp., especially in rainy season even if the average comparison performed do not show a significant difference. Among the creeks, Djibi sand careers and Dibi cemetery sites with low levels of dissolved oxygen presented the higher levels of Vibrio sp., indicating that these creeks are much more affected by wastewater pollution compared to Djibi garbage and Djibi bridge. In order to preserve the river water quality, the implementation of wastewaters treatment plants in the Djibi watershed and the limitation of water uses for domestic purposes are recommended.

\section{Acknowledgement}

This research project is funded by the AMRUGE-C2D programme 20152017 of the Ivorian Ministry of Higher Education and Scientific Research and by the French Institut de Recherche pour le Development (IRD).

\section{References}

[1] W. Larry, World water day: A billion people worldwide lack safe drinking water. www.environment.about.com (Accessed on: 23.8. 2013)

[2] D.N. Anyona, G.O. Dida, P.O. Abuom, J.O. Onyuka, A.S. Matano, C.K. Kanangire, A.V.O. Ofulla, Influence of anthropogenic activities on microbial and nutrient levels along the Mara River tributaries, Kenya, Eurasia J. Biosci. 8 (2014) 1-11.

[3] Department of Water Affairs and Forestry (DWAF), South African water quality guidelines, in: S. Holmes (Ed.), Domestic Uses, Department of Water Affairs and Forestry; DWAF: Pretoria, South Africa, 1996, pp. 132-135.

[4] N.K. Ouattara, C.K.Y. Kouamé, B. Kamagaté, L.G. Droh, A. Ouattara, G. Gourène, Impact of faecal bacteria contamination on drinking water supply in Aghien Lagoon, Abidjan, Ivory Coast, Afr. J. Microbiol. Res. 12(42) (2018) 965-972.

[5] D.C. Griffith, L.A. Kelly-Hope, M.A. Miller, Review of reported cholera outbreaks worldwide, 1995-2005, Am. J. Trop. Med. Hyg. 75 (2006) 973-977.

[6] S. Chouhan, Occurrence of Escherichia coli in raw and disinfected water supply: Correlation with enteropathogens, J. Environ. Sci. Toxicol. Food Technol. 9(7) (2015) 46-55.

[7] A. Eiler, C. Gonzalez-Rey, S. Allen, S. Bertilsson, Growth response of Vibrio cholera and other Vibrio sp. to cyanobacterial dissolved organic matter and temperature in brackish water, FEMS Microbiol. Ecol. 60 (2007) 411-418.

[8] S.F. Bloomfield, M. Exner, G.M. Fara, K.J. Nath, E.A. Scott, V.C. Van der, The global burden of hygiene-related diseases in relation to the home and community, International Scientific Forum on http://www.ifhhomehygiene.org/IntegratedCRD.nsf/111e68ea0824afe1802 575070003f039/29858aa006faaa22802572970064b6e8?OpenDocument (Accessed on: 29.9.2013)

[9] WHO, Cholera 2005, Wkly. Epidemiol. Rec. 81 (2004) 297-307.

[10] K.J. Coulibaly, C.K.Y. Kouamé, K.N. Ouattara, K. Kouadio, L.N. Amon, P. Ehuié, et al., Potential pathogenic bacteria of wastewater collectors from Abidjan (Côte d'Ivoire), Int. J. Curr. Microbiol. App. Sci. 5(5) (2016) 358-369.

[11] K.D. Ekra, H. Attoh-Touré, B.V.J. Bénié, et al., Five years of cholera surveillance in Ivory Coast during social and political crisis, 2001 to 2005, Bull. Soc. Pathol. Exot. 102 (2009) 107-109.

[12] M. Dosso, A. Kacou-N'douba, K.J. Coulibaly, R. Ncho, C. Sissoko, et al., Rapport Mission Cholera IPCI ACF, Institut Pasteur de Côte d'Ivoire : Département de Bactériologie Virologie-Unité de Bactériologie Clinique $\mathrm{Cnr}$ Cholera; Département Environnement et Santé-Unité de Microbiologie Environnementale, Côte d'Ivoire, 2012.

[13] S. Diallo, D. Noufé, Z.A. Tra Bi, A. Dao, B. Kamagaté, et al., Effets de la dynamique du couvert végétal sur les écoulements dans le bassin versant de la lagune Aghien en Côte d'Ivoire, Eur. Sci. J. 14(36) (2018) 312-332.
[14] E.S. Lindstrom, M.P. Kamst-Van Agterveld, G. Zwart, Distribution of typical freshwater bacterial groups is associated with $\mathrm{pH}$, temperature, and lake water retention time, Appl. Environ. Microbiol. 71 (2005) 8201-8206.

[15] M.A. Ibekwe, M.B. Leddy, R.M. Bold, A.K. Graves, Bacterial community composition in low-flowing river water with different sources of pollutants, FEMS Microbiol. Ecol. 79 (2012) 155-166.

[16] J. Passerat, N.K. Ouattara, J.M. Mouchel, V. Rocher, P. Servais, Impact of an intense combined sewer overflow event on the microbiological water quality of the Seine River, Water Res. 45 (2011) 893-903.

[17] K.J.P. Koffi, Y.A. N'Go, K.M. Yeo, D. Koné, I. Savané, Détermination des périmètres de protection de la lagune Aghien par le calcul du temps de transfert de l'eau jusqu'à la lagune, Larhyss J. 19 (2014) 19-35.

[18] K.R. Effebi, N.Y. Jeanne, D.D. Noufé, S. Diallo, T.B.Z. Armand, et al., Activities and uses of Aghien Lagoon (South-Est of Côte d'Ivoire), J. Water Resour. Prot. 9 (2017) 11-19.

[19] U.M. Qureshimatva, R.R. Maurya, S.B. Gamit, R.D. Patel, H.A. Solanki, Determination of physico-chemical parameters and water quality index (Wqi) of Chandlodia Lake, Ahmedabad, Gujarat, India, J. Environ. Anal. Toxicol. 5 (2015) 288:1-6.

[20] A. Errich, S. El Hajjaji, L. Mandi, M. Fekhaoui, B. Rezzouki, et al., Impact of waste water on the physico-chemical quality of water sources in bed of Oued Essaquia Elhamra in South of Morocco, Int. J. Appl. Innov. Eng. Manage 5(9) (2016) 249 261.

[21] J. Rodier, B. Legube, N. Merlet, The Analysis of the water, $9^{\text {th }}$ Edn., Dunod, Paris, 2009.

[22] Godfrey Bwire, Amanda K. Debes, Environmental surveillance of Vibrio cholerae 01/0139 in the five African great lakes and other major surface water sources in Uganda, Front Microbiol. 9 (2018) 1560:1-11.

[23] ISO, Microbiology of the food chain - horizontal method for the detection, enumeration and serotyping Salmonella sp., ISO-6579-1, Switzerland, 2017.

[24] J.F. Abowei, T.M. Sikoki, Assessment of heavy metals pollution in soils an vegetation around selected industries in Lagos State, Nigeria, J. Geosci. Environ. Protect. 3 (2005) 11-19.

[25] R.A. Oluwu, O.O. Ayejuyo, G.O. Adewuyi, I.A. Adejoro, A.A.B. Denloye, et al., Determination of heavy metals in fish tissues, water and sediment from Epe and Badagry Lagoons, Lagos, Nigeria, E-J. Chem. 7(1) (2009) 215-221.

[26] J.A. Nkwoji, A. Yakub, G.E. Ajani, K.J. Balogun, K.O. Renner, et al., Seasonal variations in the water chemistry and benthic macro invertebrates of a South Western Lagos lagoon, Nigeria, J. Am. Sci. 6(3) (2010) 85-92.

[27] L. Novotny, L. Dvorska, A. Lorencova, V. Beran, I. Pavlik, Fish: a potential source of bacterial pathogens for human beings, Vet. Med. - Czech 49 (2004) 343-358.

[28] E. Páll, M. Niculae, T. Kiss, C.D. Şandru, M. Spînu, Human impact on the microbiological water quality of the rivers, J. Med. Microbiol. 62 (2013) 16351640

[29] S.M. Soto, I. Rodríguez, M.R. Rodicio, J. Vila, M.C. Mendoza, Detection of virulence determinants in clinical strains of Salmonella enterica serovar Enteritidis and mapping on macrorestriction profiles, J. Med. Microbiol. 55 (2006) 365-373.

[30] P. Chattopadhyay, Fish-catching and handling, in: R.K. Robinson (Ed.), Encyclopedia of Food Microbiology 2, Academic Press, London, 2000.

[31] G.H. Rabbani, W.B. Greenough, Food as vehicle of transmission of cholera, J. Diarhoeal. Dis. Res. 17 (1999) 1-9.

[32] P.N. Acha, B. Szyfres, Zoonoses and communicable diseases common to man and animals, Vol. I, Bacterioses and mycoses, $3^{\text {rd }}$ Ed., Scientific and Technical Publication No. 580, Pan American Health Organization, Regional Office of the WHO, Washington, USA, 2003.

[33] F.S. Lucas, C. Therial, A. Gonçalves, P. Servais, V. Rocher, J.M. Mouchel, Variation of raw wastewater microbiological quality in dry and wet weather conditions, Environ. Sci. Pollut. Res. 21 (8) (2014) 5318-5328.

[34] A.Z. Worden, M. Seidel, S. Smriga, A. Wick, F. Malfatti, D. Bartlett, F. Azam Trophic regulation of Vibrio cholerae in coastel marine waters, Environ. Microbiol. 8 (2006) 21-29.

[35] S. Baron, J. Lesne, S. Moore, E. Rossignol, S. Rebaudet, et al., No evidence of significant levels of toxigenic $V$. cholerae 01 in the Haitian Aquatic Environment During the 2012 Rainy Season, PLOS Curr. Outbreaks. 2013.

[36] S. Rebaudet, P. Gazin, R. Barrais, S. Moore, E. Rossignol, et al., The dry season in Haiti: a window of opportunity to eliminate cholera, PLoS Curr. Outbreaks, 2013 